\title{
Motivation Strategies and Goal Attainment in Private Nigerian Teaching Hospital: Lessons from Bowen University Teaching Hospital, Ogbomoso Oyo State, Nigeria
}

\author{
Jacob Olubukola Oladipo \\ Department of Management and Accounting. Ladoke Akintola University of Technology. P.M.B 4000. Ogbomoso. Oyo State. Nigeria \\ Email of corresponding author: olubukolaoladipo@ yahoo.com
}

DOI: $10.31364 /$ SCIRJ/v6.i10.2018.P1018572

http://dx.doi.org/10.31364/SCIRJ/v6.i10.2018.P1018572

\begin{abstract}
Motivation can be seen as the processes that account for an individual's intensity, direction and persistence of effort toward achieving a goal. This study examines the motivation strategies and organizational goal attainment in a private Nigerian Teaching Hospital. Multistage sampling technique was used in selecting 48 respondents. A well structured questionnaire was used to interview the respondents. Data obtained were subjected to statistical analysis (descriptive, correlation and t-test). Result shows that most of the respondents are well educated with the minimum level of Ordinary National Diploma (OND), which could enhance their productivity and performance. More than $78 \%$ of respondents had at least five years working experience. The result further revealed correlation coefficient $(0.3762)$ of the employee in the organization which was statistically $5 \%$ level of significance. This implied that there is a strong relationship between employee motivation and the organization performance in the study area. Also, the t-test result shows a t-value of 0.64 which indicated that there is no statistically difference between the motivated and demotivated employee. This might be as a result of insignificant number of the acclaimed unmotivated workers compared with the motivated ones in the study area. In conclusion, motivation increases the chance of achieving optimum employee performance and attainment of organizational objectives, therefore, better ways of motivating employees should be adopted in other to achieve optimal organizational goals.
\end{abstract}

Keywords: Motivation, Strategy, Performance, Teaching Hospital, Employee, Organizational goal.

\section{Introduction}

Strategy can simply be seen as the process of deciding in advance the basic long term goals and objectives of an enterprise, the adoption of courses of action and the allocation of resources necessary for carrying out these goals (Chandler, 1962; Ritson, 2013). Every organization formulate strategies on both human and other resources to achieve set goals been the most sensitive part which organization need to pay much attention to. Motivation being one of the numerous management's strategies of goal attainment, though 
may be financial or non-financial in nature, the ultimate focus is that employers expects additional value to be added to the organization when employees are motivated, so that the overall organizational goal becomes attainable while introducing such motivational scheme. Most organization always introduce different schemes to get the best out of their employees, however, not all of them get expected results due to reasons which are the focus of this study.

One of the important roles of management is to ensure that employees, at work, remain satisfied and rewarded through motivation strategies that is consistent with organizational objectives (Ukaejiofo, 2013). Most privately owned health institutions in developing nations face a major challenge of inadequate employee performance. The reasons are clearly not only due to a shortage of equipment, facilities and skills, but also to lack of commitment and willingness to put effort into the job. They lay more emphasis on profit maximization objective more than any other issues while little or no attention is been paid to employee welfare and development. This account for why most health workers are not putting in their best. To this end, they experience high rate of labour turnover while the achievement of set organization objectives become a mirage. A highly motivated employee tend to energetically and committedly pursue the attainment of the organization goal for sustainability and for ensuring that it remains a going concern as against that of a demotivated ones who may be negatively inclined toward the organization. Motivation is thus the management intention of achieving a goal, an ability to change behaviour, that inner directing drive, leading to goal-directed behaviour towards the attaining goal. Rewards can be either non-monetary or monetary.

Non-monetary may be inform of awards, recognition, praises among others while monetary rewards may include salary increment, commission, over time allowance, thirteenth month payments etc. The management's target of using this strategy is to induce their employees to go extra miles in other that the organization may achieve their objectives. Fulfillment of needs results in some type of reward, which can be either intrinsic or extrinsic (Caroline, 2010). The former are derived from within the individual, that is, one taking pride and feeling satisfied about a job well-done, while the latter explains rewards given by another person (Lambruo et al., 2010). Zameer et al., (2014) posited that today organizations can easily change all resources except for humans'. From this illustration, it can be deduced that, human resource is very important or most competitive assets of any organization which cannot be easily exchangeable thus, motivation is the main factor that affects the human resources performance of the organization.

Pamela (2015) described motivation as the key of a successful organization which ensures that work is maintained in a powerful manner to aid organizations survival. According to Lydia Bank (1997:9), motivation is an internal state, like emotion and attitudes, which only the individual can control. Managers can, however, create a workplace environment that will inspire and support strong motivation on the part of employees.

Like in other fields of endeavor, health profession has been faced with goal attainment problems due largely to the perceived un-motivational strategies put in place by management of health institutions most particularly in Africa. Ratanawongsa et al (2003) observed that the workforce in the health sector has specific features that cannot be ignored and motivation can play an integral role in 
many of the compelling challenges facing healthcare today. Employees of different organizations feel the impact of motivational efforts differently thus, what motivates individual employees remains complex and diverse. To this extent, the same motivational strategies and leadership styles are unlikely to have the same impact on employees of different health institutions. (Matsie, 2008). The behaviour and motivational strategy put in place can significantly influence health system performance because there have been reported cases of low level health workers motivation in developing countries.(Okello,2015; Mathaeuer, 2006).

The term motivation, according to Kreitner and Kinicki (2004), reported in Matsie 2008, is derived from the Latin word 'movere' (to move). Motivation represents those psychological processes that cause the arousal, direction, and persistence of voluntary actions that are goal-directed.

Herselman (2001) defined motivation as "a series of energizing forces that originate both within and beyond an individual's self'. Such forces determine the nature, intensity and duration of a person's work behaviour and therefore influence their productivity.

Managers are to make things happened through the collective effort of committed and dedicated employees (Robbins, 2001). To achieve this, different policies, strategies and external motivators aimed at encouraging employees' performance must be implemented. Drake et al. (2007) and Pamela, (2015) indicated that highly motivated employees are a critical factor in the long-term success of organizations. In other words, a motivated employee is an asset while a demotivated one is a liability to the organization. Nilsson and Stomberg (2008), as well as by Roseanne Daniel (2008), revealed that opportunities for growth, working conditions and supervision help to increase employees' motivation. Fringe benefits, allowances and salaries also contribute to employees' motivation levels (Barker, 2006; Mbindyo et al., 2009; Pillay, 2009). Therefore, if specific satisfiers and dissatisfiers were identified, perhaps such factors could be altered to contribute to the number of satisfiers and, thus, to workers'overall levels of motivation (May, 2008). Psychologists have studied human motivation extensively and have formulated a variety of theories about what motivates people.

Needs-based/ content theories include Maslow's hierarchy of need, Aldersfer's theory, Herzberg's two factor theory. Another approach focuses on external factors and their role in understanding employee motivation (e.g. Skinner's reinforcement theory). Theories based on intrinsic factors focus on internal thought processes and perceptions about motivation. For the purpose of this study, both the content and reinforcement theories will be discussed as they are found to be most suitable. Abraham Maslow with his theory of "Hierarchy of needs" of 1943 which is best explained with the diagram below 


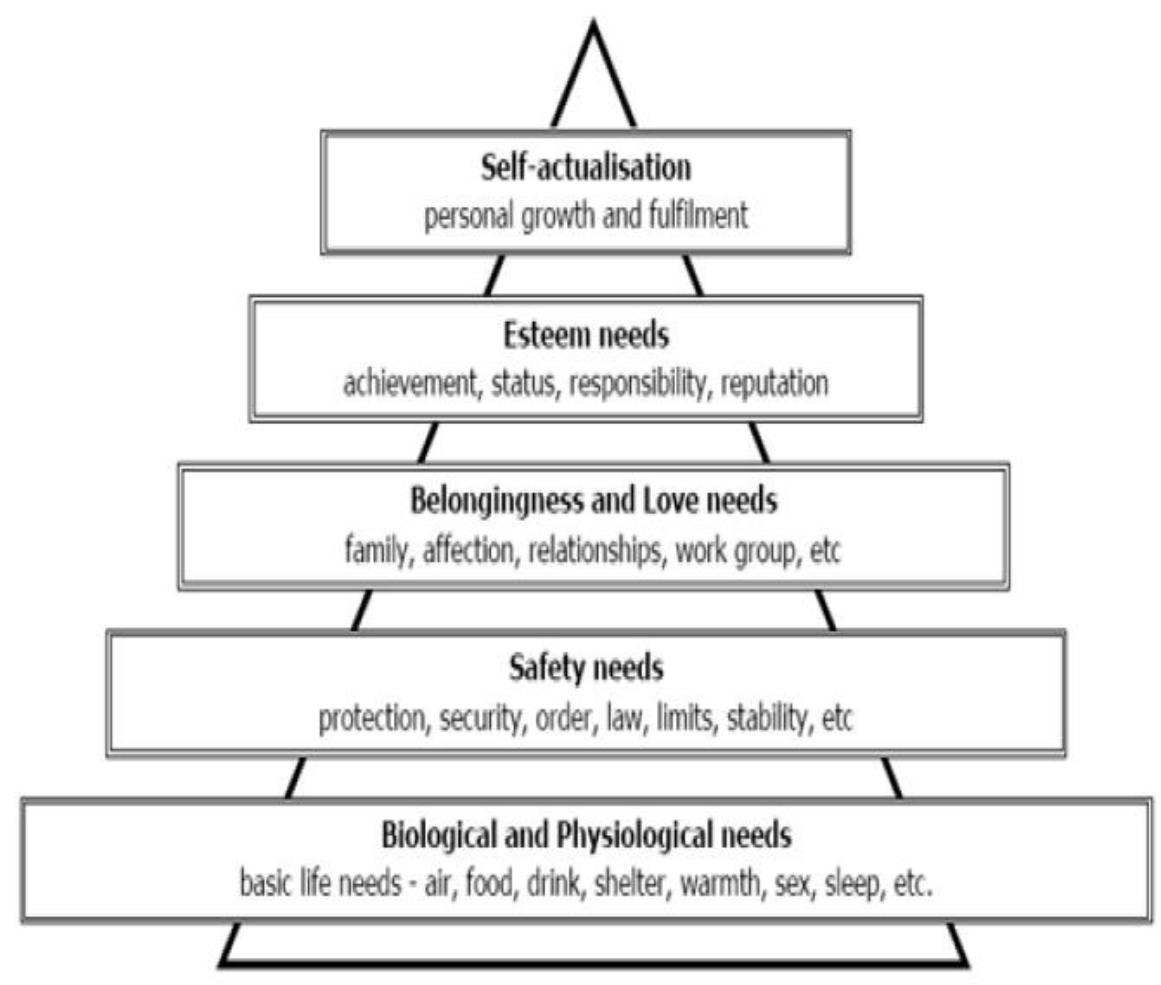

Figure 1: Abraham Maslow hierachy of need (Beardwell and Claydon)

\section{Maslow's Hierarchy of Need Theory (Figure 1)}

The "motivation to work" published in 1954 by Maslow probably provided an insight into how management perceives the job attitude and behaviour of employees with a view to understanding how well they can be motivated.(Beardwell and Claydon,1994). Probably the best-known conceptualization of human needs in organizations has been proposed by this theory. According to Maslow, if people needs re not met in an environment where they live, they're not likely to function as healthy beings. Specifically, Maslow theorized five types of needs believing them to be in a hierarchical manner. He opined that needs come in particular order starting from the least to the highest such that satisfaction of the least one brings about the urge to satisfy the next on the hierarchy till the topmost on the pyramid is reached. He further stressed that unless man understands where his/her needs falls on the pyramid, he may indefinitely remained unmotivated.

Anyim et al (2012) were of the opinion that physiological needs are the driving force and are also known as basic or felt needs. In a like manner, Chintallo and Mahadeo(2013) argued that human needs remained unsatisfied as long as his/her basic needs remain unmet. Illustratively, an hungry employee is highly unlikely to contribute anything meaningful to the realization of organization goals.

Safety need. 
This refers to the provision of security and safety in a working environment. Organizations can provide these need by providing employees with safety working equipment e.g. helmet, protective wear, health insurance schemes among others. The intent is to assure the employees of management commitment to their safety and allay their fear of any harm while carrying out their duties.

\section{Social need or Belongings needs.}

This means the need to be socialized, that is, (to be loved and accepted by other people). For these needs to be met, organizations tries to encourage employees' participation in social events such as picnics, get-together, cocktails, award nights and organizations bowling etc. By interacting among themselves, workers tend to fulfill these needs. In other to promote team work and achieve the organizational goal, managers may insist that the workers form themselves group or team while performing assigned task.

\section{Esteem needs}

Esteem needs refers to the need to earn self-respect and the esteem of others. Maslow believes that the need for goodwill, prestige, fame, honour, dominance, recognition and approval of others etc. occupy the mind of man at this level. This is other wisely known egoistic needs.

\section{Self-actualization need}

This represents the last identified needs on Maslow hierarchy of need's pyramid. It simply explains the ability of man to becoming whatever he intends or wishes to become in life. Most research on the application of need theory found that although bottom-level managers may only be able to satisfy their deficient needs on the jobs, top level managers of organizations are usually able to satisfy both their deficiency and advancement needs. (Greenberg \& Baron, 2003) this view was supported by Shipley \& Kiely, (1988) argue that as " need satisfaction is an attitude, and that it is perfectly possible for a worker to be satisfied with his/her need, but not be motivated the reverse of which holds equally true. Health workers are not immune against the yearning for these needs either be it as medical or non-medical staff, senior or junior cadre staff and management staff as the case may be. Although it may not follow in that order/sequence, it is believed that health workers have some needs that motivate them.

In a related manner, Greenberg and Baron (2003) stated that the five needs identified by Maslow correspond with the three needs of Alderfers ERG theory. Whereas Maslow theory specifies that the needs be activated in order from lowest to highest, Alder's theory specifies that the needs can be activated in any order. Alder specifies that there exist three main needs as opposed to five postulated by Maslow. This human basic needs include existence, relatedness and growth. These needs according to Alder need not necessarily activated in any specific order and may be activated at any time due to individual differences and expectancy. According to him Existence needs corresponds to Maslows physiological needs and safety needs. Relatedness needs corresponds to Maslows social needs and growth needs corresponds to esteem and self-actualization needs by Maslow.

\section{Herzberg's two factor theory}


Herzberg had the notion that those factors which cause job satisfaction are the opposite to those that causes job dissatisfaction. His studies came up with the conclusion that employees are influenced by two factors that are; the motivators and the hygiene factors. Motivators create job satisfactions which include achievement, recognition, autonomy and other intrinsic aspects when they are fulfilled. On the other hand, the hygiene factors will enhance dissatisfaction when they are not fulfilled. Motiva-tors are those factors which provide feeling of job satisfaction at work. These factors influence the ways of work in a company; for example giving responsibility to carry an enlarge task within an organization and providing the person with the necessary conditions will lead to growth and advancement to higher level tasks. Motivators are those factors which come from within an individual that is intrinsic. Herzberg hygiene factors create a suitable work environment though not increase in satisfaction. For instance low pay can cause job dissatisfaction which will affect employees' performance. Typical hygiene factors are salary, working condition, status, company policies and administration. (Saiyadain 2009). Professional and ethical independence at work by the medical personnel can better be linked to Herzberg's two-factor theory. 


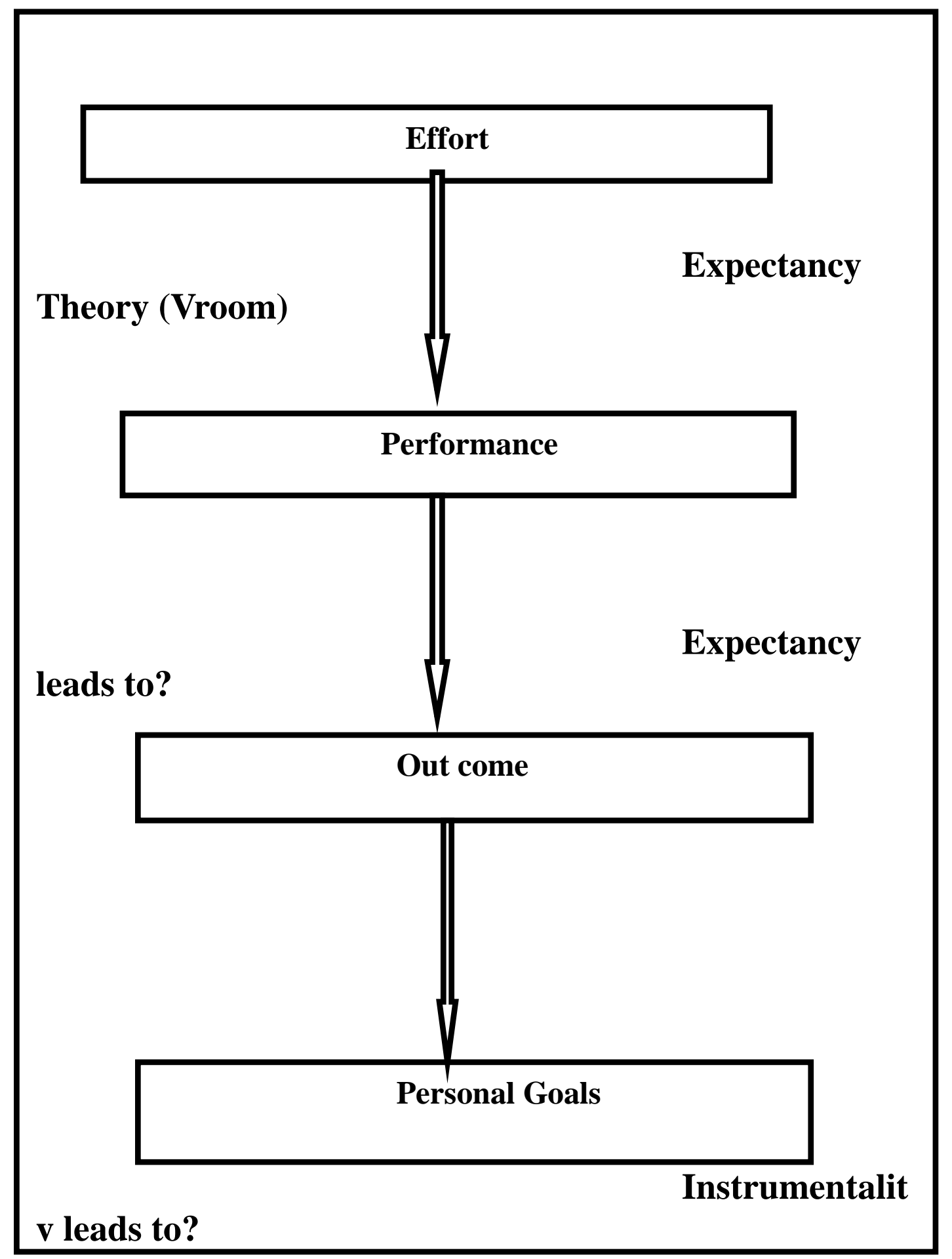

Figure 2: Vroom's Expectancy Theory

Vroom Expectancy theory. (Figure 2)

Rue and Byars (2003) state that, "the expectancy approach to motivation is based on the idea that employee beliefs about the relationship between effort, performance and outcomes are as a result of the value they place on the outcome that determine their level www.scirj.org 
of motivation", as illustrated below:

Vroom (1964) offered an expectancy approach to the understanding of the concept "motivation". Motivation simply put is a product of the value a person in action anticipates/ expects. He assumed that the possibility of having a person's goals accomplished is a product of the anticipated values in an action hence the building of Vroom' model around the concepts of valence, expectancy and force. While Valence explains the individual's preference strength for an outcome, the strength may either be negative or positive as the case may be. Expectancy is thus the probability that a certain act will lead to an anticipated outcome. To this end, the employee's motivation from Vroom point of view may be consummated by changing the perception of the employees in relation to their expectancy level through better communication and re-echoing of the actual reward that will likely result.

This theory clarifies the relationship existing between employees and goals attainment in the organizational thereby recognizing the individual differences in employees as a pointer to work motivation. However, the theory has proven difficult to researchers with difficulties confronted with its practical application.(Bose, 2004). What can be learned from different motivational theories is the fact that employees in the health sector i.e. teaching hospitals do have different needs that they must satisfy, whether these needs happen in hierarchical order, or whether they are related to the nature of employees' work; some might even be personal which they may find ways to fulfill through their job. It is important to acknowledge the fact that motivation is generated or derived from personal desire to fulfill personal needs and this can be enhanced to improve job performance for overall organizations goal attainment.

Equity theory

One thing that is common for humans is to compare themselves to others. As depicted by Carrel and Dittrich (2008), majority of theorists discussing the equity theory do posit three primary points. First and foremost, employees expect to earn a fair return for their contribution to the organization. Secondly, employees most times juxtapose, in social comparison manner, what their compensation should be with that of their colleagues within the organization or elsewhere. Lastly any employee that perceives him/ her to be inequitably treated will thrive to minimize the extent of the inequity. Robbins (2003) and Adams (1963; 1965, in Harder, 1991) see equity theory as one that centers on perceived fairness to an individual. To validate this, an employee reflects on how much, in effort, he has put into the system and subsequently compares this with his reward from it. If the employee perceives that his input-output ratio is reasonably equal to ratios of other relevant colleagues, a state of equity exists. Otherwise, there exist the feeling of been shortchanged.

There are three types of equity namely external, internal, employee equity (Konopaske and Werner, 2002). When employee compares his present state with others who have the same job but work in different organization, external equity is said to exist. On the other hand, when employees compare themselves to others who have different job but work in the same organization, we talk of internal equity. Finally, employee equity is said to exist when an employee tries comparing himself to others who occupy the same job within the same organization. The equity theory is selected for the study because it becomes interesting to see how health workers in 
general in teaching hospitals compare themselves to each other. These comparisons are capable of leading to high job turnover rate so long some employees perceive unfair treatment. Immediately a health employee feels that there is a clear case of inequality or unfairness in treatment, his morale is hampered, performance distorted and organization's goal attainment dismantled.

Broadly, this work intends to determine the motivation strategies and goal attainment in Bowen University Teaching Hospital (BUTH) of Nigeria. Other specific objectives are; to ascertain the motivational mix strategy that can be adopted in BOWEN University Teaching Hospital to engender outstanding employee performance; to investigate the attitudinal pattern to work of the motivated and unmotivated employee in relation to goal attainment in BUTH; to also examine the relationship that exist between employee motivation, performance and growth of BUTH.

This study will fill a research gap by considering the entire health workers (both clinical and non-clinical) of which paucity of work presently exist in Nigeria health system in relation to motivation and goal attainment.

\section{Research Methodology}

The study was conducted through descriptive survey design. Information on the motivation strategies and goal attainment in private Nigeria teaching hospital (BUTH) Ogbomoso was presented as received from the respondents. Selection of this design was due to the fact that it helped the researcher to explore the existing status of motivation in BUTH and establish the effective management of motivational systems in BUTH. Oyo State, Nigeria.

The study was conducted from all levels of employees to have unbiased representation from all categories of work force that represent different opinion in the hospital. At least three to five respondents were included in each category. They include:

Medical Doctors, Laboratory personnel, Pharmacists, X- ray department staff, Administrative officers, Nurses, Health and Records personnel, Finance and Accounts staff, Maintenance department staff,

To gather information on this topic, a structured questionnaire, whereby all respondents were asked the same questions and offered the same options in answering them was administered on employees of BUTH through their administrative head. There is a total of over 700 staff in BUTH. They are from different section and units mentioned above. Each of Department and units were represented in the survey while about $11.90 \%$ of the respondents do not agree most times about the statement. 50 questionnaires were distributed to employees in different categories and levels randomly; representing $7.14 \%$ of the total staff. A total of 42 questionnaires were returned, which represented $84 \%$ of all questionnaires distributed, and $16 \%$ were not received back from the employees. The researcher ensured that none of the respondents have spent less than two (2) years in the system so as to ascertain that the respondents understand the system very well and to give adequate response that will bring out the true situation. The researcher wanted to make sure that people who answered the questions have knowledge about the hospital and at least have had a few evaluations, training opportunities, and different working experience within the hospital. 


\section{Results and Discussion}

Data Presentation and Analysis

The data was tabulated, and then analyzed by the use of descriptive statistical analysis technique, i.e. Pearson product moment correlation and t- test. Results were then summarized in tables, charts and graphs. The five-point likert scale was also used to measure the extent of the Bowen Teaching Hospital employees' perception on motivation. Data analysis enabled the researcher to make conclusions on the motivation strategies and employees' performance in BUT H employees.

Table 1 show that $52.38 \%$ of the respondents were male while about $47.62 \%$ are female. Also, $(66.67 \%)$ of the hospital staffs were married, $28.57 \%$ are single. About $40.48 \%$ of the respondents fell between the ages of 31 and 40 years, $33.33 \%$ fell between 21 and 30 years old, about $16.67 \%$ were more than 50 years old while only $9.52 \%$ are between the ages of 41 and 50 years. This reveals that most of the workers are young and viable which could give better performance with their job. The result further revealed that about 26.19\% of the respondents had Higher National Diploma (HND) certificate, while $23.81 \%$ had B.Sc. degree. About $21.43 \%$ had other qualification (Professional certificate), $16.67 \%$ has certificate in nursing profession, $7.14 \%$ had National Diploma (ND) and about $4.76 \%$ had master degree (M.Sc./MBA). This really shows that most of the employee are highly educated which could enhance their productivity and performance.

Furthermore, about 37\% had worked between 11 and 15 years in the hospital, 23.81\% had working experience between 6 and 10 years, while about $21.43 \%$ has less than 5 year working experience. Also, about $11.90 \%$ had more than 20 years working experience while only $7.14 \%$ had between 16 and 20 years working experience. The result shows that large number of the respondents had good working experience. Similar method of demographic/ personal data analysis can be found in the works of Muogbo, 2013 and Lambrou et.al., 2010.

\section{Table 1: Socio-economic characteristics of the respondents}

\begin{tabular}{|c|c|c|}
\hline Variables & Frequency & Percentage \\
\hline \multicolumn{3}{|l|}{ Gender } \\
\hline Male & 22 & 52.38 \\
\hline Female & 20 & 47.62 \\
\hline \multicolumn{3}{|c|}{ Marital Status } \\
\hline Single & 12 & 28.57 \\
\hline Married & 28 & 66.67 \\
\hline No response & 2 & 4.76 \\
\hline \multicolumn{3}{|l|}{ Age } \\
\hline $21-30$ & 14 & 33.33 \\
\hline $31-40$ & 17 & 40.48 \\
\hline
\end{tabular}




\begin{tabular}{|lcc|}
\hline $41-50$ & 4 & 9.52 \\
\hline Above 50 & 7 & 16.67 \\
\hline Education Status & & \\
\hline OND & 3 & 7.14 \\
\hline HND & 11 & 26.19 \\
\hline Nursing Certificate & 7 & 16.67 \\
\hline B.Sc. & 10 & 23.81 \\
\hline M.Sc./MBA & 2 & 4.76 \\
\hline Professional certificate & 9 & 21.43 \\
\hline Work experience (Years) & & \\
\hline Less than 5 & 9 & 21.43 \\
\hline 6-10 & 10 & 23.81 \\
\hline 11-15 & 15 & 35.71 \\
\hline 16-20 & 3 & 7.14 \\
\hline Above 20 & 5 & 11.90 \\
\hline Total & 45 & 100.00 \\
\hline Source Author &
\end{tabular}

\section{Source: Author's computation, 2018}

Table 2 revealed the response of the employee to motivation strategies. Most (92.6\%) of the respondents agree that motivation do assist the management to get best performance, while only $7.14 \%$ disagree. About $97.62 \%$ agreed that employees perform better if they are well motivated and agreed that performance are well motivated through benefit, while $21.43 \%$ disagree. Also, most $(88.10 \%)$ of the respondents had the understanding of the types of motivation and (85.71\%) of them prefer financial motivation. This finding also concurs with that of Matsie (2008). Ukaejiofo (2013). Arising from the study, larger percentage of the respondents felt that motivation strategies do assist the management to get best performance from employees with an infinitesimal percentage feeling otherwise. Same goes for the fact that employees perform better if they are well motivated as well as the fact that most of the respondents had the understanding of the types of motivation in operation and rather prefer financial to non-financial motivation.

\section{Table 2: Motivation strategy}

\begin{tabular}{lccc}
\hline Statements & Agree & Not agree & Indifferent \\
\hline Motivation assists management to get best performance. & 92.86 & 7.14 & - \\
Employee perform better if well motivated & 97.62 & 2.38 & - \\
Performance motivated be benefit & 73.81 & 21.43 & 4.76 \\
Understanding of motivation types & 88.10 & 11.90 & - \\
Financial motivation preferred & 85.71 & 11.90 & 2.38 \\
\hline
\end{tabular}

Source: Authors computation, 2018 
The result as shown in Table 3 revealed that $42.86 \%$ of the respondents strongly agree with management recognition of outstanding performance, $33.33 \%$ agree with this statement most time while only $14.29 \%$ always agreed with the statement. This implied that most of the employees in the study area do agree with the fact that the institution management does recognize outstanding performance of their employee. Also, about $50 \%$ of the employees strongly agree to the fact that management always reward outstanding performance of their employees, $23.81 \%$ agree most of the time and $11.90 \%$ always agree with the statement. About $45.24 \%$ of the employees in the study area strongly agree that management of their institution are concerned with their welfare, 28.81\% agree most times. Furthermore, strongly $50 \%$ of the respondents agreed that the management communicate performance to employee and larger part (42.86\%) of the employees strongly agreed that the management is efficient with about $40.48 \%$ that strongly agree that the management achieve their set goals. This is in consonance with the findings of Caroline,(2010). Most of the employees in the study area did agree with the fact that the institution management does recognize and reward outstanding performance and well concerned with their welfare. Furthermore, management is seen to always communicate performance to employee which led to management achieving its goals with greater efficiency. On a general note, management carries out its employee's supervision role effectively

Table 3: Management supervision

\begin{tabular}{|c|c|c|c|c|}
\hline Statements & MTA & SA ANA NA & ID & \\
\hline \multicolumn{5}{|l|}{ Management recognition of outstanding } \\
\hline performance & $14.29 \quad 33.33$ & $42.86 \quad 4.76 \quad 2$ & $2.38 \quad 2$ & 2.38 \\
\hline Management rewards outstanding performance & e $11.90 \quad 23.81$ & $50.00 \quad 11.90$ & - & 2.38 \\
\hline Management concern on employee welfare & 28.81 & 45.2411 .90 & $0 \quad 2.38$ & 84.76 \\
\hline \multicolumn{5}{|l|}{ Management communicate performance to } \\
\hline employee & 21.43 & 50.00 & 2.38 & 2.38 \\
\hline Management is efficient & 38.10 & 42.86 & - & 2.38 \\
\hline Management achieves its objective & 14.29 & 40.48 & - & 2.38 \\
\hline
\end{tabular}

\section{Source: Authors computation, 2018}

\section{Note:}

AA = Always agree, $\mathrm{MTA}=$ Most time agree, $\mathrm{SA}=$ strongly agree

ANA $=$ Always never agree, $\mathrm{NA}=$ Never agree, $\mathrm{ID}=$ Indifferent.

Table 4 shows the correlation coefficient (0.3762) of the employee in the organization. The correlation coefficient was positive and statistically significant at 5\% level of significance. The result revealed that, there is a strong relationship between employees' 
motivation and the organization performance in the study area. This is in line with the findings of Zameer et al (2014). Muogbo(2013) Alhassan et al(2013) With the results from findings, the correlation coefficient which is positive and statistically significant shows that there is a strong relationship between employees' motivation and the organization performance in the study area. Thus, since employees are better motivated, the organization is better for it.

Table 4: Relationship between employee motivation and organization performance

\begin{tabular}{lcc}
\hline Group & No of respondents & Correlation coefficient \\
\hline Pooled & 42 & $0.3762^{*}$ \\
Motivated & 33 & $0.3400^{*}$ \\
Non motivated & 9 & 0.8213 \\
& & \\
\hline
\end{tabular}

Source: Author's computation, 2018.

The result presented in Table 5 revealed the average value for the motivated and the acclaimed demotivated employee to be 0.66 and 0.62 , the difference was 0.04 and the $\mathrm{t}$-value of 0.64 . This shows that there is no statistically difference between the motivated and demotivated employee. This might be as a result of insignificant number of the acclaimed demotivated workers in the study area. In terms of attitudinal and behavioural pattern to work of the motivated and the demotivated employees of BUTH, there is no significant difference noticed. This according to findings may not be unconnected with the insignificant number of the acclaimed demotivated employees who work with the organization.

Table 5: t-test showing attitudinal differences in the motivated and demotivated employees.

\begin{tabular}{llllll}
\hline Group & Obs & Mean & Std. Err. & Std. Dev. & T-value \\
\hline Motivated & 33 & 0.66 & 0.03 & 0.17 & 0.64 \\
Demotivated & 9 & 0.62 & 0.0 & 0.19 & \\
Combined & 42 & 0.65 & 0.03 & 0.17 & \\
Difference & 0.04 & 0.06 & & & \\
& & & & & \\
\end{tabular}




\section{Source: Author's computation, 2018.}

\section{Conclusion}

This study tries to examine the motivation strategies and Goal attainment in Private Nigerian Teaching Hospital with particular reference to BOWEN University Teaching Hospital, Ogbomoso. After a critical evaluation in line with the objectives of the study, it was concluded that, the employees of BUTH, Ogbomoso have better understanding of what motivation is and what constitute acceptable blend/mix of motivational techniques. But they are less satisfied with the management's present choice and implementation of motivational tools. They believe that the management is not doing enough at motivating them and this has hitherto affected their commitment and loyalty capable of engendering outstanding performance both at individual and organizational level. BUTH's employees want the management to improve on its mode of motivating them with a reasonable blend of both financial and non-financial techniques. Based on the findings, it is recommended that BUTH's management should have a critical look at and improve on its motivation technique so as to secured employees' assured loyalty and commitment that can lead to the attainment of set organizational objectives capable of making it second to none in the provision of universally accepted healthcare services. The management should also have comprehensive employees' motivation scheme, subject to continuous review in line with economic realities and capabilities of all times. A reasonable blend/mix of motivational tools should also be considered for implementation by the hospital management so that windows of varieties of choices could be opened to the employees bearing in mind the concept of individuality and need insatiable tendencies of employees.

\section{References}

Anyim , C., Chidi, O., and Badejo, A. (2012). Motivation and Employees' performance in the Public and Private Sectors in Nigeria: International Journal of Business Administration. 3 (1):31- 40

Barker , A. M (2006). Transformational Nursing leadership: a vision for the future. Fairfield: Jones and Bartlett.

Beardwell,J. and Claydon, T. (1994) Human Resource Management. $5^{\text {th }}$ ed.Great brain: Pearson Education Limited, pp 1-740

Bose , C . D (2004). Principles of Management and Administration. Prentice - Hall of India Limited.

Carolina ,M.(2010) The impact of a reward system on employee motivation in Motonet -Espoo. Degree thesis. International Business.

$1-51$

Chintalloo, S. and Mahadeo, J. (2013). Effect of Motivation on Employees' work performance at Ireland Blyth Limited: Proceedings of $8^{\text {th }}$ Annual London Business Research Conference Imperial College, London, UK. 1-16

Drake ,A. R., Wrong, J. and Salter, S.B(2007). Empowerment, motivation and performance: examining the impact of feedback and 
incentives on non-management employees. Behavioural Research in Accounting, 19: 71-89.

Greenberg,J and Baron, A. R (2003) “Behaviour in organization” Prentice Hall, 8: 188 - 215

Herselman, S.(2001). Performance motivation among employees of a wholesale company. Journal of Ethonology, 24(1): 1 -10.

Kreitner , R. and Kinicki, A. (2004). Organizational behaviour: New York: McGraw- Hill.

Lambrou ,P,. Kontodimopoulos, $\mathrm{N}$ and Niakas, D(2010). Motivation and job satisfaction among Medical and Nursing staff in a Cyprus Public general hospital.8(26):1-9

Lydia, B.(1997). Motivation in the workplace: Inspiring your employees. Coastal Training Technologies Corp. USA. 1-111

Mathauer, I and Imhoff, I.(2006). Health worker motivation in Africa: the role of non-financial incentives and human resource management tools. Human Resources for Health. 4 (24):1 -17.

Matsie, M. A. T (2008). The impact of motivation on employee performance at level one district Hospitals, with special reference to mestimaholo district hospital in Sosolburg. Mini - dissertation of Masters in Business Administration at the North- west University (Vanderbijlpark Campus).

Maslow, A.H. (1954). Motivation and personality, $2^{\text {nd }}$ ed, Happer and Row,1 - 369.

May , A. A (2008). A study of Nurse practitioner job satisfaction in Florida. Unpublished Master's thesis. Miami : Florida State University College of Nursing.1-13

Mbindyo, P. M,. Blaauw, D., Gilson, L., and English, M.(2009). Developing a tool to measure health worker motivation in district hospitals in Kenya. Human Resources for Health, 4(43):1 -11

Melkeidezek ,T. L,. Eustance, P. Y. M,. Mwangu, M. A., and Naboth, A.A.M(2008). Motivation of Healthcare workers in Tanzania: A case study of Muhimbili National Hospital. East African Journal of Public Health. 5( 1.) 32-37

Nilsson , K.E., and Stomberg, M.I.W.(2008). Nursing students' motivation towards their studies: a survey study. Biomed Central Nursing. 7(8): 6.

Okello , D.O.R and Gilson, L.(2015). Exploring the influence of trust relationships on motivation in the health sector: a systematic review. Human Resource for Health. 13:16.

Pamela , A.O(2015). Effect of motivation on employee performance of commercial banks in Kenya: A case study of Kenya Commercial bank in Migori County. International Journal of Human Resources Studies 5 (2):87-102

Pillay, R.(2009). Work satisfaction of professional nurses in SA: a comparative analysis of the public and private sectors. Human Resources for Health, 7(15): 7 -15.

Ratanawongsa N, Howell, E.E, and Wright S.M(2006). What motivate physciances throughout their carrers in medicine? Compr Ther.32(4):210 -217

Ritson ,N(2013). Strategic Management. Bookboon.com. $2^{\text {nd }}$ ed. 1-117 WWW.scirj.org 
Robbins , S.P(2001). Organizational behaviour. New jersey. Prentice Hall. $9^{\text {th }}$ ed. 1-105

Roseanne, C.M and Daniel, J.P(2006). Application and extension of motivation theory to professional nursing work. Journal of Health Organization and management, 20(1) : :15-48.

Saiyadain , M(2009). Human Resources Management. Mc.Graw-Hill, inc.Shipley, D. and Kiely, J (1988) Motivation and Dissatisfaction of Industrial workers - How relevant is Maslow theory. European Journal of Marketing 22 (1): 17-24

Ukaejiofo, R.U.(2013). Impact of motivation on employees' performance: A case study of credit west bank Cyprus. Journal of Economics and International Finance. 5(5):199-211

Zameer, H., Ali. S, Nisar, W, and Amir, M.(2014). The impact of motivation on employee's performance in beverages Industry of Pakistan. International Journal of Academic research in Accounting, finance and management science. 4(1).293-298 